\title{
Why vitamin D for cancer patients?
}

\author{
S Gandini ${ }^{1}$, FP Francesco ${ }^{2}$, H Johanson $^{3}$, B Bonanni $^{3}$ and A Testori ${ }^{2}$ \\ ${ }^{1}$ Epidemiology and Biostatistics Division, ${ }^{2}$ Melanoma and Muscle-Cutaneous Sarcomas Division, ${ }^{3}$ Cancer Prevention and Genetics Division, European \\ Institute of Oncology, Milan, Italy.
}

\section{Abstract}

Several epidemiological, pre-clinical and clinical studies support Vitamin D as a preventive and therapeutic cancer agent.

\section{Background}

Vitamin D and cancer: calcitriol, the biologically active form of vitamin $D(1,25(O H) D)$, exerts its effects mainly through binding to nuclear vitamin D receptor (VDR). Calcitriol has been shown to be an anti-proliferative, pro-differentiation, pro-apoptotic agent and an inhibitor of cell migration. Animal and human in vitro studies strongly indicate that vitamin $D$ may have benefits for many forms of cancer. Inadequate levels of circulating 25-hydroxy-vitamin $\mathrm{D}(25(\mathrm{OH}) \mathrm{D})$ are associated with an increased risk and poor prognosis of several types of cancer.

Vitamin D and melanoma: cutaneous malignant melanoma (CMM) represents a major public health issue: rates in Italy have almost doubled in the last decade and CMM is frequent among young adults. For resected stage II melanoma no standard adjuvant treatment exists and five-year overall survival is about $70 \%$.

Cultured melanoma cells can synthesize calcitriol from 25(OH)D and express the VDR. Moreover, 1,25(OH)D has anti-proliferative and pro-differentiation effects in human melanoma cells. 1,25(OH)D has been shown to induce apoptosis in human melanoma cell lines and has an inhibitory effect on the spreading of melanoma cells in vitro.

Preliminary results on vitamin D: epidemiological data indicate that vitamin D deficiency is relatively common in Europe. In an Italian study, we found that $85 \%$ of the participants had insufficient levels of $25(\mathrm{OH}) \mathrm{D}$. We have shown through a meta-analysis of randomized trials that vitamin $D$ supplementation is associated with a significant reduction (7\%) in total mortality in healthy subjects and an association between VDR and $25(\mathrm{OH}) \mathrm{D}$ and CMM progression has also been demonstrated. We have also reported significant associations between VDR polymorphisms and incidence of skin cancer. In early supplementation trials, the lack of effect on cancer incidence has been attributed to insufficient vitamin $D$ supplementation, stressing the need to better study vitamin $D$ bioavailability.

In fact, a recent IARC report highlighted the need for new randomized trials, based on results from our meta-analyses on 25(OH)D serum levels and cancer risk.

Clinical trial and biomarkers studies: in order to assess whether vitamin D supplementation could improve prognosis of CMM, an Italian multi-centre trial in stage II resected melanoma patients was planned to monitor changes in $25(\mathrm{OH}) \mathrm{D}$. The study will address two important questions regarding the relationship between the biology of VDR and (1) vitamin D metabolism, and (2) CMM prognosis. This will involve investigating the association between VDR polymorphisms and Breslow thickness, the most important prognostic factor of CMM, and between $25(\mathrm{OH}) \mathrm{D}$ serum level, vitamin D supplementation and VDR.

We will also evaluate at baseline whether VDR polymorphisms are associated with Breslow thickness and whether we obtain significant increase in $25(\mathrm{OH}) \mathrm{D}$ serum levels during the first year of supplementation. We will quantify the percentages of patients who have desirable levels of $25(\mathrm{OH}) \mathrm{D}$ and, if they don't, the mean time to reach that level. The findings from this study will be of great interest because vitamin $D$ could have anti-cancer benefits for a wide spectrum of cancers.

Published: 30/09/2009

Received: 30/07/2009

ecancer 2009, 3:160 DOI: 10.3332/ecancer.2009.160

Copyright: (c) the authors; licensee ecancermedicalscience. This is an Open Access article distributed under the terms of the Creative Commons Attribution License (http://creativecommons.org/licenses/by/2.0), which permits unrestricted use, distribution, and reproduction in any medium, provided the original work is properly cited.

Competing Interests: The authors have declared that no competing interests exist.

Correspondence to S Gandini. Email: sara.gandini@ieo.it 


\section{Background and rationale}

\section{Biological background}

Cancer chemoprevention uses natural, synthetic or biologic agents to reverse, suppress or prevent carcinogenic progression. Genetic changes exist throughout the process and increase the likelihood that one or more pre-malignant and malignant lesions may develop within that process. Multi-step carcinogenesis describes a stepwise accumulation of alterations, both genotypic and phenotypic. Arresting one or several of the steps may impede or at least delay the development of cancer.

Several epidemiological, pre-clinical and clinical studies support vitamin $D$ as a preventive and therapeutic cancer agent, for a wide spectrum of cancers.

Calcitriol (1,25-dihydroxyvitamin D [1,25(OH) D]), the hormonal derivative of vitamin $\mathrm{D}$, has been established since the 1980s as an anti-proliferative and pro-differentiation agent and as a pro-apoptotic agent and an inhibitor of cell migration, which may imply an inhibitory effect on cancer [1].

Vitamin $D$ is indeed more like a hormone and not strictly a vitamin according to the classical criteria that an essential nutrient is a substance the body cannot synthesize in sufficient quantities itself. Also, vitamins are usually involved in biochemical reactions, while $1 \alpha, 25$-dihydroxyvitamin $D$ exerts its action via VDR.

Vitamin $D$ represents a group of fat-soluble pro-hormones, the two major forms of which are vitamin $D_{2}$ (or ergocalciferol) and vitamin $\mathrm{D}_{3}$ (or cholecalciferol). Endogenous synthesis of vitamin $D_{3}$ takes place in the skin under the influence of ultra-violet $B$ (UVB) radiation. Exogenous vitamin $D_{2}$ or $D_{3}$ comes from dietary intake. The overall vitamin $D$ intake is the sum of cutaneous vitamin $\mathrm{D}$ and nutritional vitamin $\mathrm{D}$.

Vitamin $D$ on its own has no physiological action. To be physiologically active, vitamin $D$ must first be hydroxylated in the liver by the enzyme 25-hydroxylase, encoded by CYP27A1 (also called the 25-hydroxylase or 25(OH)D), into 25hydroxyvitamin $\mathrm{D}$. The 25-hydroxyvitamin $\mathrm{D}$ is inactive, and an additional hydroxylation in the kidney by the enzyme $1 \alpha$ hydroxylase, encoded by CYP27B1 (also called 41ahydroxylase), is necessary to produce the physiologically active vitamin $\mathrm{D}$ metabolite, calcitriol or $1,25(\mathrm{OH}) \mathrm{D}$. When $1,25(\mathrm{OH}) \mathrm{D}$ is sufficiently available, the enzyme mitochondrial protein encoded by CYP24A1 metabolises the 1,25(OH)D into $1 \alpha, 24,25$-dihydroxyvitamin $D$, which is further catabolised to calcitroic acid. $25(\mathrm{OH}) \mathrm{D}$ and $1,25(\mathrm{OH}) \mathrm{D}$ are transported in serum by the vitamin D-binding protein (GC). Ahn et al systematically investigated the association of 48 SNPS in four vitamin D metabolising genes (CYP27A1, GC, CYP27B1 and CYP24A1) with serum 25(OH)D levels. Four tagSNPS in GC, the major serum 25(OH)D carrier, were associated with $25(\mathrm{OH}) \mathrm{D}$ levels [2].

\section{VDR and cancer risk}

The vitamin D receptor (VDR) gene is involved in multiple pathways that may be important in the aetiology of cancer. The importance of dietary calcium, vitamin $D$, energy and fat in modifying the association between VDR genotype and cancer risk has been shown repeatedly. In addition to these dietary factors that modify cancer risk, BMl and age also appear to be 'effect modifiers' of the association between VDR and cancer.

We performed a meta-analysis on the association between the two most studied VDR polymorphisms (Fokl and Bsml) and cancer at any site. When comparing Fokl ff with FF carriers, we found a significant increase in skin cancer (SOR; 95\% confidence intervals $(\mathrm{Cl}): 1.30 ; 1.04-1.61)$ and breast cancer (SOR; 95\%Cl: 1.14; 1.03-1.27) risk. For the same genotype comparison, we found a significantly higher risk of cancer when we pooled estimates from cancer sites possibly associated with vitamin D levels (prostate, breast, skin, ovary, non-Hodgkin lymphoma). A significant reduction in prostate cancer risk was observed for carriers of Bsml Bb compared with bb genotype (SOR; 95\%Cl: 0.83; 0.69-0.99). In Caucasian populations, both $\mathrm{Bb}$ and $\mathrm{BB}$ carriers had a significant reduced risk of cancer at any site. In conclusion, this meta-analysis showed that VDR Fokl and Bsml polymorphisms may modulate the risk of cancer of the breast, skin and prostate and possibly affect cancer risk at any site in Caucasians [3].

\section{Sources of vitamin D}

There is good evidence from randomized trials that a dietary intake of vitamin $D$ increases serum levels of 25-hydroxyvitamin D [4]. However, only a few foods naturally contain appreciable enough amounts of vitamin $D$ to have an impact either through the form of cholecalciferol (vitamin D3) derived from animal sources, or ergocalciferol (vitamin D2), from plant food. It has been verified that fatty fish such as salmon, mackerel and 
bluefish, cod-liver oil, egg yolks, sun-dried mushrooms and yeasts are excellent sources of vitamin $D_{3}$.

Most of an individuals vitamin D supply is provided through endogenous synthesis of vitamin $D_{3}$ upon sunshine exposure and will depend on amounts of UVB reaching earth surface, on skin surface exposed to UVB and on skin pigmentation. Many factors influence the amount of UVB radiation reaching the Earth's surface.

In summary, these factors include:

- $\quad$ UVB is mainly present in sunlight between 10 am and 3 pm solar hours.

- The season: UVB is more abundant during the summer or the hot season.

- $\quad$ Place of residence.

- Meteorology: clouds may filter out much of the UVB, even at the equator.

- The UVB-induced synthesis of vitamin $D_{3}$ in human skin is additionally dependent on several factors, including:

time spent out-of-doors (evaluation of continuous pattern versus intermittent pattern of sun exposure);

skin type, pigmentation;

age of subjects, as endogenous skin synthesis capacity decreases with age;

- $\quad$ Sun protection habits, mainly in populations where clothing (garments and veils) covers most of the skin surface.

- Results from a study by Adams et al [61] also show that the serum level of $25(\mathrm{OH}) \mathrm{D}$ is more stable than vitamin $\mathrm{D}$. Because of its relatively long half-life ( $\mathrm{T} 1 / 2=12.9$ (SD: 3.6 d)) [5], the serum 25(OH)D level is considered as the best gauge of individual vitamin $\mathrm{D}$ status.

\section{Vitamin D and mortality from all causes}

We published a meta-analysis of published randomized trials, which showed a significant reduction of $7 \%$ in total mortality (RR $0.93, p<0.05)$ in subjects taking vitamin D. Eighty-two percent of patients received vitamin $D_{3}$ (cholecalciferol), the remaining vitamin $D_{2}$ (ergocalciferol), either orally or by injection. Average daily doses ranged from 300 to $2000 \mathrm{IU}$. Treatment ranged from daily to four-monthly, and follow-up ranged from six months to seven years. Our main recommendation in light of the results from this study was the conduction of large population-based randomized trials of prolonged vitamin $D_{3}$ treatment [6]. The
Netherlands Longitudinal Aging Study examined, during a sixyear follow-up, the risk of death of 1260 community dwelling people 65 years old or more according to serum 25(OH)D levels measured at baseline [7]. The results indicated that subjects with serum $25(\mathrm{OH}) \mathrm{D}$ levels lower than $20 \mathrm{ng} / \mathrm{ml}$ had a mortality risk associated with steadily lower levels (log-rank test: $\mathrm{p}<0.0001$ ).

In the Third National Health and Nutrition Examination Survey (NHANES III, USA) 13,331 adults, 20 years or older, were followed for a median of 8.7 years [8]. There were 1806 deaths, 777 from cardiovascular disease (CVD) and 424 from cancer. Serum 25(OH)D levels below $17.8 \mathrm{ng} / \mathrm{ml}$ were associated with a $26 \%$ increased rate of all-cause mortality [mortality rate ratio (95\% Cl: $+8 \% ;+46 \%)$.

\section{Epidemiological evidence and optimal serum levels of 25(OH)D}

So far epidemiological data for cancer prognosis argue for an overall positive role of sun-induced vitamin $\mathrm{D}$. The ratios of death rates to incidence rates suggest that cancer prognosis improves with decreasing latitude. UV exposure is a realistic explanation since it is unlikely that cancer treatment is better in Australia than in the United Kingdom [9].

Genetic variations would be phenotypically apparent as interindividual variations in limiting rates of vitamin $D$ synthesis in the skin, hydroxylation in the liver and in the kidney, transport, metabolism, degradation would ultimately influence individual vitamin $\mathrm{D}$ status. These genetic differences would also be reflected in the numerous variants of the VDR, some of which have different affinity for 1,25(OH)D.

In general modern society is vitamin $\mathrm{D}$ deprived compared with prehistoric humans. The concentrations of $25(\mathrm{OH}) \mathrm{D}$ observed today are based on contemporary cultural norms (clothing, sun avoidance, food choices and legislation).

Inadequate levels of circulating $25(\mathrm{OH}) \mathrm{D}$ are associated with an increased risk and poor prognosis of several types of cancer [10-12].

Giovannucci estimated the relationship between plasma $25(\mathrm{OH}) \mathrm{D}$ and several risk factors (skin colour, obesity, latitude and physical activity) for cancer. The associations between these factors and total cancer incidence and mortality in their large cohort ( $~ 50,000$ subjects) could be accounted for an by an increment of $25 \mathrm{nmol} / \mathrm{l}$ in $25(\mathrm{OH}) \mathrm{D}$, which reduces mortality by $29 \%$ for all cancers and $45 \%$ for digestive cancers [10]. These results are consistent with a marked direct effect of vitamin $D$ on 
cancer incidence and mortality, but they could be at least partly due to confounding factors. This can be resolved only by a randomized trial.

A prospective study examined the association between prediagnostic $25(\mathrm{OH}) \mathrm{D}$ levels and mortality in patients diagnosed with colorectal cancer within the Nurses' Health Study (NHS) and the Health Professionals Follow-Up Study (HPFS). This study showed that higher pre-diagnostic plasma 25(OH)D levels were associated with a significant improvement in overall survival [13]: individuals with vitamin D levels in the highest quartile were $48 \%$ less likely to die (from any cause) than those with the lowest vitamin D levels (adjusted HR of $0.52: 95 \% \mathrm{Cl}$, 0.29 to 0.94 ), with a linear and statistically significant trend. The odds of dying from colon cancer specifically were $39 \%$ lower (HR of $0.61 ; 95 \% \mathrm{Cl}, 0.31$ to 1.19). The authors highlight the need for well-designed prognostic studies among cohorts of cancer patients, in which exposure assessments are uniformly obtained after diagnosis and information on prognostic tumour characteristics is also available. Several studies show promising results, but a randomized trial among cancer patients would be essential to obtain an unequivocal answer on whether cancer patients should be advised to take vitamin D supplements [14]. A German cohort study of 3299 patients referred for coronary angiography recorded, during a median 7.8 years of follow-up, 736 deaths, among which 95 were attributed to a cancer [15]. After adjusting for common confounders (e.g. sex, age, obesity, smoking status, physical exercise) the study found a twofold increased risk (95\% Cl: 1.01-3.8) for a cancer-related death in patients with serum 25(OH)D levels below $15 \mathrm{ng} / \mathrm{ml}$, as compared to patients with higher serum concentrations. This risk did not vary in patients with serum levels higher than 15 $\mathrm{ng} / \mathrm{ml}$.

A working group of experts, organized by the International Agency for Cancer Research, carried out meta-analyses on 25(OH)D serum levels and colorectal cancer incidence. We observed a significant reduction in risk comparing the highest levels versus the lowest level of $25(\mathrm{OH}) \mathrm{D}$; pooled RR: 0.6 $(95 \% \mathrm{Cl}: 0.4,0.7)$, with a significant dose-response effect. Among the studies included, the lowest values of $25(\mathrm{OH}) \mathrm{D}$ for the upper categories in average were $34 \mathrm{mg} / \mathrm{ml}$ and the upper levels of the lowest category was $18 \mathrm{mg} / \mathrm{ml}$ [59].

Vitamin $D$ deficiency is defined by most experts as a $25(\mathrm{OH}) \mathrm{D}$ level of less than $20 \mathrm{ng} / \mathrm{ml}(50 \mathrm{nmol} / \mathrm{l})[16,17]$. By these standards both the European and US populations are vitamin D insufficient or deficient. The total $25(\mathrm{OH}) \mathrm{D}$, that is $25(\mathrm{OH}) \mathrm{D}_{2}$ plus $25(\mathrm{OH}) \mathrm{D}_{3}$, is what physicians need to be aware of in their patients.
The estimated optimal serum $25(\mathrm{OH}) \mathrm{D}$ level for prevention of colorectal carcinoma and adenoma is $90 \mathrm{nmol} / \mathrm{l}$ or higher, a conclusion supported by the $\mathrm{NIH}$-sponsored symposium on vitamin $\mathrm{D}$ and cancer $[18,19]$.

In a trial (IEO 007) carried out by our Cancer Prevention and Genetics Division in pre-menopausal Italian women at high risk of breast cancer, we found that $85 \%$ had at insufficient level of $25(\mathrm{OH}) \mathrm{D}$, considering as cut-off point $75 \mathrm{nmol} / \mathrm{l}$. The results were presented at the AACR (2008).

Current efforts to assess optimal serum concentrations of $25(\mathrm{OH}) \mathrm{D}$ generally focus on bone health in older white persons, and the common definition of the optimal level has been the concentration that maximally suppresses serum parathyroid hormone (PTH). In most persons, the optimal level cannot be reached with the currently recommended intake of 200 and 600 IU/d for younger and older adults, respectively.

The Women's Health Initiative (WHI) in the USA [20], a randomized trial evaluating the influence of $400 \mathrm{IU}$ of vitamin D supplementation per day, plus calcium, showed negative results on all cancer risk. However, findings from the nested casecontrol study demonstrated a significant inverse trend with lower baseline levels of serum $25(\mathrm{OH}) \mathrm{D}$ associated with an increased risk of colorectal cancer ( $p$ for trend $=0.02$ ). Commentaries on the negative findings of the $\mathrm{WHI}$ trial suggest that too-low vitamin $\mathrm{D}$ doses, too-short trial duration, addition of calcium and low compliance to supplementation may be an explanation $[21,22]$.

The results of the nested case-control study organised within the WHI trial including colorectal cancer cases and 317 matched controls, showed that the risk of colorectal cancer increased with decreasing serum 25-hydroxyvitamin $D$ levels in subjects with low-vitamin D status at baseline, before use of supplements or placebo. Results from these trials stress the need to better study vitamin D bio-availability.

A recent study on prognostic effects of circulating $25(\mathrm{OH}) \mathrm{D}$ in a cohort of patients with early breast cancer found that deficient levels of vitamin $D$ were associated with higher grade tumours, suggesting that the prognostic effect of vitamin $D$ may be due, in part, to the development of higher grade tumours in vitamin D-deficient women, consistent with a potential role of vitamin D in breast carcinogenesis [23].

\section{Safety and toxicity of vitamin D}

Cholecalciferol accumulates in adipose and muscular tissue to be available when the body needs it. 
A daily treatment of $2000 \mathrm{IU}$ of Vitamin $\mathrm{D}_{3}$, the safe upper-intake limit as defined by the National Academy of Sciences, should increase circulating $25(\mathrm{OH}) \mathrm{D}$ to the desired level.

Thus $2000 \mathrm{IU}$ is the safe recommended daily allowance even at the higher end of the normal $25(\mathrm{OH}) \mathrm{D}$ serum concentration level [24-29].

All the published reports of Vitamin $D$ toxicity with convincing evidence of hypercalcemia involve serum 25(OH)D concentrations well above $200 \mathrm{nmol} / \mathrm{l}$, which requires a daily intake of more than 40, 000IU, and which could be conservatively considered the lowest observed adverse effect level (LOAL).

Vitamin $D$ intoxication is observed when serum levels of 25hydroxyvitamin $D$ are greater than $150 \mathrm{ng} / \mathrm{ml}(374 \mathrm{nmol} / \mathrm{l})$. Vitamin $\mathrm{D}$ intoxication is extremely rare but can be caused by inadvertent or intentional ingestion of excessively high doses. Doses of more than $50,000 \mathrm{IU} / \mathrm{d}$ raise levels of $25(\mathrm{OH}) \mathrm{D}$ to more than $150 \mathrm{ng} / \mathrm{ml}(374 \mathrm{nmol} / \mathrm{l})$ and are associated with hypercalcemia and hyperphosphatemia $[30,31,32]$.

Trivedi et al in their trial on fractures and mortality reported no side effects in over 2000 subjects aged 65 or over receiving 2.5 $\mathrm{mg}$ po four-monthly or placebo for five years [33]. The Women's Health Initiative trial reported a $17 \%$ increase in the risk of kidney stones among post-menopausal women receiving $10 \mu \mathrm{g}$ of vitamin and $1000 \mathrm{mg}$ of elemental calcium per day [34], but this was probably due to the calcium supplements, and not the vitamin $D$ supplement. Other randomized trials testing vitamin $D$ supplementation did not report higher incidence of kidney stones [4].

\section{Compliance}

In the study by Trivedi et al a compliance of at least $80 \%(\geq 12$ of 15 tablets posted four-monthly over five years) was achieved in $76 \%$ of randomized subjects. In this study, subjects received tablets four-monthly, with a freepost reply to report whether the tablet was taken and reasons for not taking it [33]. However, in the WHI study compliance to supplementation was low. Throughout the entire trial duration, only $50-60 \%$ of women took $80 \%$ of the scheduled supplementation regimen [20].

In our meta-analysis of 18 randomized trials on intakes of vitamin $D$ and overall mortality, eight of these trials reported increases in serum 25-hydroxyvitamin $D$ level in the intervention group, but variations ranged from a factor 1.4-5.2 mainly because of compliance issues [6].

\section{Vitamin D and melanoma, epidemiological evidence}

Relatively few epidemiologic studies have directly addressed the relationship between vitamin $D$ and the incidence or prognosis of cutaneous malignant melanoma (CMM).

Increasing incidence of skin cancer starting around the 1950s has been described in all light-skinned populations. These increases concerned all types of skin cancer. The most recent cancer registry data show that skin cancer incidence is still rising in nearly all light-skinned populations. Cutaneous malignant melanoma represents a major public health problem in many countries throughout the world. Over the past several decades, its incidence has increased more rapidly than that of any other cancer, although fortunately this increase has not been accompanied by a similar rise in mortality rates, possibly reflecting beneficial effects of awareness and prevention programmes. In Italy, the age-adjusted incidence is 4.6 per 100,000 person per year in males and 5.5 in females, with higher mortality rates being documented in Northern rather than in Southern Italy [35-37]. In Italy, the incidence of CMM has increased: rates have almost doubled in the last ten years. $\mathrm{CMM}$ is a disease of young subjects $(>50 \%$ of all cases are diagnosed below the age of 60 years), and for Stage II melanoma no treatment can be offered to the patients after surgery.

The CMM fatality over five years was observed to be $40-60 \%$ less in people with a history of high sun exposure independently of body site, thickness, mitotic rate and early detection behaviour. The study by Berwick et al involved mostly patients with early stage melanoma, and it is plausible that the known anti-proliferative and anti-angiogenic properties of vitamin $D$ may be inversely associated with melanoma progression. However, it should be noted that solar elastosis and other sun exposure markers in the study reflected pre-diagnostic exposures to sunlight [38]. Sunburn and intermittent sun exposure are well-known risk factors for CMM; however, continuous pattern of sun exposure seems to be inversely associated to melanoma $[39,40]$. Thus, it is not clear whether the results of Berwick et al reflect benefits related to continued sunlight exposure and an association with vitamin $D$ intake, or a different pathogenesis in melanomas that arise in persons at risk to develop actinic skin damage.

Exposure to UVB increases endogenous vitamin $D$ synthesis and risk of skin cancer. However, skin synthesis of vitamin $D$ is self-limited and in light-skinned people fades away after 5-10 minutes. Longer durations of sun exposure will not further increase vitamin $D$, but will increase skin cancer risk. 
Furthermore, within an IARC working group, we showed that exposure to artificial UV light from sun beds increases the risk of melanoma and SCC, especially when the first exposure takes place before 35 years of age [41].

The incidence of melanoma of the skin on intermittently exposed sites is reduced among outdoor workers compared with indoor workers [42]. This pattern of incidence among workers has usually been attributed to the fact that a more continuous pattern of sun exposure may reduce the incidence of sunburns, a known melanoma risk factor. However, an alternative hypothesis is that outdoor workers are less likely to be deficient in vitamin $D$ because of their more regular exposure to sunlight.

Seasonal variation in serum 25(OH)D levels is well known [43], and the winter level of serum $25(\mathrm{OH}) \mathrm{D}$ is considered the best indicator of an individual's real vitamin $\mathrm{D}$ status.

Boniol et al showed significant variations in incidence and fatality of melanoma with relation to season of diagnosis. There was also a $16 \%(95 \% \mathrm{Cl}:-6 \% ;-28 \%)$ decrease in the multivariate adjusted fatality rate between winter and summer after adjustment for Breslow thickness, suggesting other factors apart from earlier diagnosis influence survival, for instance a late promotional effect of greater exposure to UV in the summer [44]. An Italian study found significantly increased survival in melanoma patients who had intermittent sun exposure before diagnosis [45].

A study population of 212 patients with histologically proven cutaneous melanomas showed that progression of malignant melanoma was associated with statistically significantly reduced $25(\mathrm{OH}) \mathrm{D}$ serum levels [46].

\section{Vitamin D and melanoma, biological evidence}

Cultured melanoma cells can synthesize $1,25(\mathrm{OH})_{2} \mathrm{D}_{3}$ from $25(\mathrm{OH}) \mathrm{D}_{3}$, express the VDR and proliferate more slowly in response to $1,25(\mathrm{OH})_{2} \mathrm{D}_{3}$ [47-49]. Moreover, $1,25(\mathrm{OH})_{2} \mathrm{D}_{3}$ has been shown to suppress the growth of human malignant melanoma (MM)-derived xenografts (expressing the VDR) in immunosuppressed mice, but not in a VDR-negative MM cell line. The $1,25(\mathrm{OH})_{2} \mathrm{D}_{3}$ molecule has been shown to induce apoptosis in a human MM cell line in vitro, and an inhibitory effect on the spread of MM cells has been demonstrated in vitro [50].

Upon the activation by $1,25(\mathrm{OH})_{2} \mathrm{D}_{3}$, the VDR mediates its effects by regulating the transcription of other genes. The VDR gene is located on chromosome $12 q 12-q 14$, and it has at least
196 single nucleotide polymorphisms, some of which seem to influence the activity of $1,25(\mathrm{OH})_{2} \mathrm{D}_{3}$. Among VDR polymorphisms, the most frequently investigated for their association with various cancers are Fokl (exon 2, rs10735810), which results in an altered translation start site and has been shown to be functionally relevant [51], and Bsml (intron 8, rs1544410), which seems to be associated with different diseases, although its function is still under debate $[52,53]$.

\section{A meta-analysis on vitamin $D$ receptor polymorphisms and skin cancer}

A meta-analysis suggests a possible significant role of VDR Fokl and Bsml polymorphisms in CMM and non-melanoma skin cancer (NMSC): the Fokl $f$ allele showed a positive association with CMM and NMSC, whereas the Bsml B allele showed a significantly negative association with CMM [54]. Further studies on the role of VDR polymorphisms in skin cancer development could be useful to better understand these associations.

\section{Serum levels of 25(OH)D, VD R and melanoma prognosis}

A cohort study was carried out in Leeds (UK) to test the hypothesis that higher vitamin $D$ levels reduce the risk of relapse from melanoma. A prospective survival analysis in this cohort of 872 patients showed that higher 25-hydroxyvitamin D3 levels, at diagnosis were associated with lower Breslow thickness at diagnosis $(p=0.002)$ and were independently protective of relapse and death: the hazard ratio for relapse-free survival (RFS) was $0.79(95 \% \mathrm{Cl}, 0.64$ to $0.96 ; p=0.01)$ for a 20 $\mathrm{nmol} / \mathrm{l}$ increase in serum level. There was evidence of interaction between the vitamin D receptor (VDR) Bsml genotype and serum 25-hydroxyvitamin D3 levels on RFS [55].

Two studies evaluating serum levels of $25(\mathrm{OH}) \mathrm{D}$ and skin cancer risk $[46,56]$ reported lower basal $25(\mathrm{OH}) \mathrm{D}$ levels in melanoma patients compared to the control group, although this difference was statistically not significant. Bishop evaluated the risk of relapse for CMM patients taking vitamin D supplementation and found a significant reduced risk: 0.54 $(0.32-0.92)$. The results were presented as an abstract publication [56]. Moreover, Nurnberg [46] found that progression of malignant melanoma was associated with statistically significantly reduced $25(\mathrm{OH})$ D serum levels. Two other studies found an association of VDR polymorphisms with Breslow thickness $[57,58]$, suggesting a role for vitamin $D$ in the CMM prognosis. 
Halsall et al evaluated also a novel adenine-guanine substitution -1012 bp relative to the exon 1a transcription start site $(A-1012 G)$ of the vitamin D receptor. The $\boldsymbol{A}$ allele was overrepresented in CMM patients $(p=0.007)$. The outcome was related to the development of metastasis, the Kaplan-Meier estimates of the probability of metastasis at five years being: GG 0\%; AG 9\%, Cl 4-16\%; AA 21\%, Cl 12-36\%; ( $p=0.008)$, and to thicker Breslow thickness groups $(p=0.04)$. The effect on metastasis was independent of tumour thickness and A-1012G may have predictive potential, additional to Breslow thickness. Fokl and Taql variants were strongly related to the thickest Breslow thickness group $(p=0.005)$. There was an interaction between the A-1012G and Fokl polymorphisms $(p=0.025)$ and the Fokl variant enhanced the effect of the $\boldsymbol{A}$ allele of the $\boldsymbol{A}$ $1012 \mathrm{G}$ polymorphism on metastasis, the probability of metastasis for AAff at a five-year follow-up being $57 \%, \mathrm{Cl} 24-$ $92 \%[57]$.

\section{The need for a trial on vitamin D supplementation}

Vitamin D is a drug, more precisely, a hormone. The experience accumulated in the last 20 years with chemoprevention and hormonal substances shows that no compound should be recommended for cancer chemoprevention if its efficacy and side effects have not been evaluated in large, randomized trials. Laboratory data and observational studies should only be considered as indicative of potential for chemopreventive use.

Findings from prospective cohort studies on colorectal cancer risk and on mortality constitute pieces of evidence strong enough to consider that randomized trials of vitamin $D$ use and cancer mortality may not have correctly addressed the question, and that new randomized trials should be organized.

Some groups advocate increasing vitamin D status (e.g. above $30 \mathrm{ng} / \mathrm{ml}$ of serum 25-hydroxyvitamin D) through more exposure to ultraviolet radiation or through taking high doses of vitamin $D$ supplements (i.e. more than $50 \mu \mathrm{g} / \mathrm{d}$ or more). However, sun exposure is also a well-known risk factor for certain cancers and, as for any drug, before issuing claims on health benefit and promoting recommendations for increasing substantially the vitamin D status of millions of individuals, the alleged claims must be tested via randomized controlled trials for evaluation of efficacy on primary endpoint(s) [59].

\section{The issue of the dose}

The estimated optimal serum 25(OH)D for prevention of cancer equal to or greater than $30 \mathrm{ng} / \mathrm{ml}$ is a conclusion supported by the $\mathrm{NIH}$-sponsored symposium on vitamin D and cancer $[18,19]$.
Results from the meta-analyses on $25(\mathrm{OH}) \mathrm{D}$ serum levels and cancer incidence, within the working group of experts, organized by the International Agency for Cancer Research, showed a significant reduction in risk for colorectal cancer comparing the highest levels versus the lowest level of 25(OH)D, with a significant dose-response effect [59]. Among the studies included, the lowest values of $25(\mathrm{OH}) \mathrm{D}$ for the upper categories on average were about $30 \mathrm{mg} / \mathrm{ml}$ and the upper levels of the lowest category was $18 \mathrm{mg} / \mathrm{ml}$.

In a trial (IEO 007) carried out by the Cancer Prevention and Genetics Division of the European Institute of Oncology in premenopausal women at high risk of breast cancer, we found that $85 \%$ had insufficient levels of $25(\mathrm{OH}) \mathrm{D}$, considering $30 \mathrm{ng} / \mathrm{m}$ as cut-off point.

It has been calculated that $2000 \mathrm{IU} / \mathrm{d}$ should shift the NHANES III distribution so that only $10-15 \%$ of persons had concentrations $<30 \mathrm{ng} / \mathrm{ml}$, which are observed in healthy outdoor workers.

This dose is not toxic and necessary to achieve the optimal level of $25(\mathrm{OH}) \mathrm{D}$. A daily dose of $2000 \mathrm{IU}$ vitamin $\mathrm{D}_{3}$, the safe upper intake limit as defined by the National Academy of Sciences, should achieve the desired level of circulating 25(OH)D [17,19,24,26].

Cholecalciferol is accumulated in adipose and muscular tissue to be available when the body needs it. Vitamin $D$ intoxication is extremely rare but can be caused by inadvertent or intentional ingestion of excessively high doses. Doses of more than 50,000 $\mathrm{IU} / \mathrm{d}$ raise levels of 25-hydroxyvitamin $D$ to more than $150 \mathrm{ng} / \mathrm{ml}$ (374 nmol/l) and are associated with hypercalcemia and hyperphosphatemia $[30,31,60]$.

All of the reports of vitamin $\mathrm{D}$ toxicity showing the convincing evidence of hypercalcemia involve serum 25(OH)D concentrations well above $200 \mathrm{nmol} / \mathrm{l}$, which requires a daily intake of more than $(40,000 \mathrm{IU})$, and which could be conservatively considered the lowest observed adverse effect level $[28,29]$.

The Women's Health Initiative trial reported a $17 \%$ increase in the risk of kidney stones among post-menopausal women receiving $10 \mu \mathrm{g}$ of vitamin and $1000 \mathrm{mg}$ of elemental calcium per day ${ }^{34}$, but this increase was probably due to the calcium supplements, and not to the vitamin D. In fact other randomized trials testing vitamin $D$ supplementation did not report higher incidence of kidney stones [4].

As a result of these studies, we decided on 100,000 IU every 50 days, which corresponds to $2000 \mathrm{IU}$ daily, for the following trial on melanoma patients. 


\section{Summary of background and specific aims of an Italian multi-centre randomized placebo-controlled phase III trial}

Vitamin $D$ and cancer: calcitriol, the biologically active form of vitamin $\mathrm{D}(1,25(\mathrm{OH}) \mathrm{D})$, exerts its effects mainly through binding to the nuclear VDR. Calcitriol has been shown to be an antiproliferative, pro-differentiation, pro-apoptotic agent and an inhibitor of cell migration. Animal and human in vitro studies strongly indicate that vitamin D may be beneficial for many forms of cancer. Inadequate levels of circulating 25-hydroxyvitamin $\mathrm{D}(25(\mathrm{OH}) \mathrm{D})$ are associated with an increased risk and poor prognosis of several types of cancer.

Vitamin D and melanoma: cutaneous malignant melanoma represents a major public health problem-rates in Italy have almost doubled in the last decade and CMM is frequent among young adults. For resected stage II melanoma no standard adjuvant treatment exists and five-year overall survival is about $70 \%$.

Cultured melanoma cells can synthesize calcitriol from $25(\mathrm{OH}) \mathrm{D}$ and express the VDR. Moreover, the anti-proliferative and prodifferentiation effect of $1,25(\mathrm{OH}) \mathrm{D}$ have been found in human melanoma cells. $1,25(\mathrm{OH}) \mathrm{D}$ has been shown to induce apoptosis in human melanoma cell lines and an inhibitory effect on the spread of melanoma cells has been demonstrated in vitro.

Preliminary results on vitamin D: Epidemiological data indicate that vitamin $D$ deficiency is relatively common in Europe. In an Italian study, we found that $85 \%$ of the participants had insufficient level of $25(\mathrm{OH}) \mathrm{D}$. We show through a meta-analysis of randomized trials that vitamin $\mathrm{D}$ supplementation was associated with a significant reduction of $7 \%$ in total mortality in healthy subjects. We also reported significant associations between VDR polymorphisms and incidence of skin cancer while other studies suggest association between VDR and 25(OH)D and CMM progression. In early supplementation trials, the lack of effect on cancer incidence has been attributed to insufficient vitamin D supplementation, stressing the need to better study vitamin $\mathrm{D}$ bioavailability.

Finally, a recent IARC report highlighted the need for new randomized trials, based on results from our meta-analyses on $25(\mathrm{OH}) \mathrm{D}$ serum levels and cancer risk.

\section{Conclusions}

Several epidemiological, pre-clinical and clinical studies support vitamin $D$ as a preventive and therapeutic cancer agent, for a wide spectrum of cancer. The aim of this proposed study is to evaluate the effect of vitamin D supplementation on melanoma recurrence and mortality.

\section{Overview of study design}

We propose a randomized double-blind placebo-controlled clinical trial to evaluate whether vitamin $\mathrm{D}$ supplementation and changes of serum levels of $25(\mathrm{OH}) \mathrm{D}$ are associated with melanoma recurrence and mortality. Patients with resected stage II melanoma will be recruited in different institutes in Italy. Participants will be randomly assigned to one of the arms (100,000 IU po every 50 days, an average 2000 IU a day, versus placebo), treated for three years and followed for two years.

Recruitment will proceed simultaneously at the different centres and will be completed in four years. Complete physical examination, measurements of anthropometric and epidemiological characteristics, as measure of study compliance will be performed at baseline as well as at the interim visits, every four months. We will collect blood samples to measure vitamin D levels every four months for the first year, and annually thereafter. Vitamin D polymorphisms will be evaluated at baseline. Efficacy will be determined by assessing CMM recurrence as the primary outcome. Three are the planned interim analyses. We will also evaluate general and CMM specific mortality.

Compliance will be evaluated by self-reported number of ampoules taken, and supported by serum $25(\mathrm{OH}) \mathrm{D}_{3}$ levels.

The study will be conducted across Italian Institutes sponsored by the European Institute of Oncology. The minimum length of the follow-up period will be two years, and the end of follow-up is determined by recurrence, death or last day of the follow-up.

\section{Aims of the trial}

\section{Primary aim}

To assess the effect of Vitamin $D_{3}$ supplementation (2000 IU/day) on disease-free survival for stage II CMM patients through a randomized, placebo-controlled trial.

\section{Secondary aims}

To evaluate:

- whether vitamin D receptors (Bsml, Fokl and A-1012G polymorphisms), gene-gene interactions and serum level 
of $25(\mathrm{OH}) \mathrm{D}$ are associated with melanoma prognosis: we will assess the association at baseline between $25(\mathrm{OH}) \mathrm{D}$ serum levels, vitamin $\mathrm{D}$ receptor (VDR) polymorphisms and gene-gene interactions with Breslow thickness, the main prognostic factors;

- $\quad$ whether changes in $25(\mathrm{OH}) \mathrm{D}$ are associated with DFS or OS;

- $\quad$ whether Vitamin D receptors, CYP27A1, CYP24A1 and GC (vitamin $\mathrm{D}$ binding protein) genes are associated to serum level of $25(\mathrm{OH}) \mathrm{D}$ at baseline and with changes in $25(\mathrm{OH}) \mathrm{D}$ levels;

- $\quad$ whether $25(\mathrm{OH}) \mathrm{D}$ serum levels of vitamin $\mathrm{D}$ are associated with BMI, vitamin D food intake and fat intake;

- $\quad$ whether vitamin D receptors and 25(OH)D serum levels of vitamin $D$ are associated with other prognostic factors such as number of mitosis, gender, age, tumour location and ulceration;
- $\quad$ percentage of patients at $30 \mathrm{mg} / \mathrm{ml}$ level of $25(\mathrm{OH}) \mathrm{D}$ at one year and mean time to reach that level;

- change in overall survival (OS) in melanoma patients at stage II, taking vitamin D supplementation;

- $\quad$ the pattern of response of parathormone (PTH) following vitamin $D_{3}$ supplementation in these patients, and association with changes in $25(\mathrm{OH}) \mathrm{D}$;

- $\quad 25(\mathrm{OH}) \mathrm{D}$ serum levels and anthropometric measures (such as BMI, waist-to-hip ratio, waist-to-stature ratio), dietary intakes (vitamin D, calcium and fat intake), occupation and different patterns of sun exposures;

- $\quad$ Short and long-term safety and toxicity at $2000 \mathrm{IU} / \mathrm{d}$;

- Compliance.

Finally, we will develop a bio-repository of blood samples, collected at several time points. This will create a large biological database for future research (e.g. molecular characteristics of intervention efficacy, serum, vitamin D serum levels). 


\section{References}

1. Deeb KK, Trump DL and Johnson CS (2007) Vitamin D signalling pathways in cancer: potential for anticancer therapeutics Nat Rev Cancer 7 684-700 PMID: 17721433 doi: $10.1038 / \mathrm{nrc} 2196$

2. Ahn J, Albanes D, Berndt SI et al (2009) Vitamin D-related genes, serum vitamin $D$ concentrations and prostate cancer risk Carcinogenesis 30 769-76 PMID: 19255064 doi: 10.1093/carcin/bgp055

3. Raimondi S, Johansson $H$, Maisonneuve $P$ and Gandini $S$ (2009) Review and meta-analysis on vitamin D receptor polymorphisms and cancer risk Carcinogenesis 30 117080 PMID: 19403841 doi: 10.1093/carcin/bgp103

4. Cranney A, Horsley T, O'Donnell S et al (2007) Effectiveness and safety of vitamin $D$ in relation to bone health Evid Rep Technol Assess (full rep) 1-235 PMID: 18088161

5. Davie MW, Lawson DE, Emberson C, Barnes JL, Roberts GE and Barnes ND (1982) Vitamin D from skin: contribution to vitamin D status compared with oral vitamin $D$ in normal and anticonvulsant-treated subjects Clin Sci (Lond) 63 461-72 PMID: 6288317

6. Autier P and Gandini S (2007) Vitamin D supplementation and total mortality:a meta-analysis of randomized controlled trials Arch Intern Med 167 1730-7 PMID: 17846391 doi: 10.1001/archinte.167.16.1730

7. Visser M, Deeg DJ, Puts MT, Seidell JC and Lips P (2006) Low serum concentrations of 25-hydroxyvitamin $D$ in older persons and the risk of nursing home admission Am J Clin Nutr 84 616-22 PMID: 16960177

8. Melamed ML, Michos ED, Post W and Astor B (2008) 25hydroxyvitamin $D$ levels and the risk of mortality in the general population Arch Intern Med 168 1629-37 PMID: $\underline{18695076}$ doi: 10.1001/archinte.168.15.1629

9. Moan J, Porojnicu AC, Dahlback A and Setlow RB (2008) Addressing the health benefits and risks, involving vitamin D or skin cancer, of increased sun exposure Proc Natl Acad Sci USA 105 668-73 PMID: 18180454 doi: $\underline{10.1073 / p n a s .0710615105}$

10. Giovannucci E (2005) The epidemiology of vitamin D and cancer incidence and mortality: a review (United States) Cancer Causes Control 16 83-95 PMID: 15868450 doi: 10.1007/s10552-004-1661-4

11. Lim HS, Roychoudhuri R, Peto J, Schwartz G, Baade P and Moller $H$ (2006) Cancer survival is dependent on season of diagnosis and sunlight exposure Int J Cancer 119 1530-6 PMID: 16671100 doi: 10.1002/ijc.22052

12. Robsahm TE, Tretli S, Dahlback A and Moan J (2004) Vitamin D3 from sunlight may improve the prognosis of breast-, colon- and prostate cancer (Norway) Cancer Causes Control 15 149-58 PMID: 15017127 doi: 10.1023/B:CACO.0000019494.34403.09

13. $\mathrm{Ng} \mathrm{K}$, Meyerhardt JA, Wu K et al (2008) Circulating 25hydroxyvitamin d levels and survival in patients with colorectal cancer J Clin Oncol 26 2984-91 PMID: 18565885 doi: $10.1200 / J C O .2007 .15 .1027$

14. Ulrich CM and Holmes RS (2008) Shedding light on colorectal cancer prognosis:vitamin $\mathbf{d}$ and beyond $\mathrm{J}$ Clin Oncol 26 2937-9 PMID: 18565879 doi: 10.1200/JCO. 2008.16.1380

15. Pilz S, Dobnig H, Winklhofer-Roob B et al (2008) Low serum levels of 25-hydroxyvitamin D predict fatal cancer in patients referred to coronary angiography Cancer Epidemiol Biomarkers Prev 17 1228-33 PMID: 18463400 doi: 10.1158/1055-9965.EPI-08-0002

16. Holick MF (2007) Vitamin D deficiency N Engl J Med 357 266-81 PMID: 17634462 doi: 10.1056/NEJMra070553

17. Holick MF and Chen TC (2008) Vitamin D deficiency:a worldwide problem with health consequences $A m \mathrm{~J}$ Clin Nutr 87 1080S-6S PMID: 18400738

18. Gorham ED, Garland CF, Garland FC et al (2005) Vitamin D and prevention of colorectal cancer J Steroid Biochem Mol Biol 97 179-94 PMID: 16236494 doi: 10.1016/j.jsbmb. 2005.06.018

19. Bischoff-Ferrari HA, Giovannucci E, Willett WC, Dietrich T and Dawson-Hughes B (2006) Estimation of optimal serum concentrations of 25-hydroxyvitamin $D$ for multiple health outcomes Am J Clin Nutr 84 18-28 PMID: 16825677

20. Wactawski-Wende J, Kotchen JM, Anderson GL et al (2006) Calcium plus vitamin D supplementation and the risk of colorectal cancer N Engl J Med 354 684-96 PMID: 16481636 doi: 10.1056/NEJMoa055222

21. Holick MF (2006) Calcium plus vitamin D and the risk of colorectal cancer $N$ Engl J Med 354 2287-8. PMID: 16723623 doi: $10.1056 /$ NEJMc060753

22. Giovannucci E (2006) Calcium plus vitamin D and the risk of colorectal cancer N Engl J Med 354 2287-8 PMID: 16729368 doi: $10.1056 /$ NEJMc060753

23. Goodwin PJ, Ennis M, Pritchard $\mathrm{KI}$, Koo J and Hood N (2009) Prognostic effects of 25-hydroxyvitamin D levels in early breast cancer $J$ Clin Oncol 27 3757-63 PMID: $\underline{19451439}$ doi: $10.1200 / \mathrm{JCO} .2008 .20 .0725$

24. Institute of Medicine of the National Academies (1997) Dietary reference intakes National Academy press Serial (Book, Monograph)

25. Holick MF (2009) Vitamin D status: measurement, interpretation, and clinical application Ann Epidemiol 19 
73-8 PMID: 18329892 doi: 10.1016/i.annepidem.2007.12. $\underline{001}$

26. Calvo MS, Whiting SJ and Barton CN (2005) Vitamin D intake:a global perspective of current status J Nutr 135 310-6 PMID: 15671233

27. Bischoff-Ferrari HA, Giovannucci E, Willett WC, Dietrich T and Dawson-Hughes B (2006) Estimation of optimal serum concentrations of 25-hydroxyvitamin $D$ for multiple health outcomes Am J Clin Nutr 84 18-28 PMID: 16825677

28. Vieth $R$ (2004) Why the optimal requirement for Vitamin D3 is probably much higher than what is officially recommended for adults $\mathrm{J}$ Steroid Biochem Mol Biol 8990 575-9 PMID: 15225842 doi: 10.1016/j.jsbmb.2004.03. 038

29. Vieth R and Fraser D (2002) Vitamin D insufficiency: no recommended dietary allowance exists for this nutrient CMAJ 166 1541-2 PMID: 12074121

30. Adams JS, and Lee G (1997) Gains in bone mineral density with resolution of vitamin $\mathbf{D}$ intoxication Ann Intern Med 127 203-6 PMID: 9245225

31. Koutkia P, Chen TC and Holick MF (2001) Vitamin D intoxication associated with an over-the-counter supplement $N$ Engl J Med 345 66-7 PMID: 11439958 doi: 10.1056/NEJM200107053450115

32. Hathcock JN, Shao A, Vieth R and Heaney R (2007) Risk assessment for vitamin D Am J Clin Nutr 85 6-18 PMID: 17209171

33. Trivedi DP, Doll R and Khaw KT (2003) Effect of four monthly oral vitamin D3 (cholecalciferol) supplementation on fractures and mortality in men and women living in the community: randomised double blind controlled trial BMJ 326469 PMID: 12609940 doi: $\underline{10.1136 / \mathrm{bmj} .326 .7387 .469}$

34. Jackson RD, LaCroix AZ, Gass M et al (2006) Calcium plus vitamin $D$ supplementation and the risk of fractures $N$ Engl J Med 354 669-83 PMID: 16481635 doi: 10.1056/NEJMoa055218

35. Ferlay J, Autier P, Boniol M, Heanue M, Colombet $\mathrm{M}$ and Boyle P (2007) Estimates of the cancer incidence and mortality in Europe in 2006 Ann Oncol 18 581-92 PMID: 17287242 doi: 10.1093/annonc/mdl498

36. Kamangar F, Dores GM and Anderson WF (2006) Patterns of cancer incidence, mortality, and prevalence across five continents: defining priorities to reduce cancer disparities in different geographic regions of the world J Clin Oncol 24 2137-50 PMID: 16682732 doi: 10.1200/ JCO.2005.05.2308

37. de Vries E, Bray FI, Coebergh JW and Parkin DM (2003) Changing epidemiology of malignant cutaneous melanoma in Europe 1953-1997: rising trends in incidence and mortality but recent stabilizations in western Europe and decreases in Scandinavia Int J Cancer 107 119-26 PMID: 12925966 doi: 10.1002/ijc. 11360

38. Berwick M, Armstrong BK, Ben-Porat $L$ et al (2005) Sun exposure and mortality from melanoma $\mathrm{J}$ Natl Cancer Inst 97 195-9 PMID: 15687362

39. Gandini S, Sera F, Cattaruzza MS et al (2005) Metaanalysis of risk factors for cutaneous melanoma: II. Sun exposure Eur J Cancer 41 45-60 PMID: 15617990

40. Caini S, Gandini S, Sera F et al (2009) Meta-analysis of risk factors for cutaneous melanoma according to anatomical site and clinico-pathological variant Eur J Cancer 45 3054-63 PMID: 19545997

41. IARC Working group (2007) The association of use of sunbeds with cutaneous malignant melanoma and other skin cancers: A systematic review Int J Cancer 120 1116-22 PMID: 17131335 doi: 10.1002/ijc.22453

42. Elwood JM, Gallagher RP, Hill GB and Pearson JC (1985) Cutaneous melanoma in relation to intermittent and constant sun exposure-the Western Canada Melanoma Study Int J Cancer 35 427-33 PMID: 3988369 doi: $10.1002 / i j c .2910350403$

43. Stamp TC and Round JM (1974) Seasonal changes in human plasma levels of 25-hydroxyvitamin D Nature 247 563-5 PMID: 4818557 doi: 10.1038/247563a0

44. Boniol M, Armstrong BK and Dore JF (2006) Variation in incidence and fatality of melanoma by season of diagnosis in new South Wales, Australia Cancer Epidemiol Biomarkers Prev 15 524-6 PMID: 16537711 doi: 10.1158/1055-9965.EPI-05-0684

45. Rosso S, Sera F, Segnan N and Zanetti R (2008) Sun exposure prior to diagnosis is associated with improved survival in melanoma patients:results from a long-term follow-up study of Italian patients Eur J Cancer 44 1275-81 PMID: 18406602 doi: 10.1016/j.ejca. $\underline{2008.03 .009}$

46. Nurnberg B, Graber S, Gartner B et al (2009) Reduced serum 25-hydroxyvitamin $D$ levels in stage IV melanoma patients Anticancer Res 29 3669-74 PMID: 19667163

47. Oberyszyn TM (2008) Non-melanoma skin cancer:importance of gender, immunosuppressive status and vitamin D Cancer Lett 261 127-36 PMID: 18267352

48. Seifert M, Rech M, Meineke V, Tilgen $\mathrm{W}$ and Reichrath $\mathrm{J}$ (2004) Differential biological effects of 1,25dihydroxyVitamin D3 on melanoma cell lines in vitro $\mathrm{J}$ Steroid Biochem Mol Biol 89-90 375-9 PMID: 15225804 doi: 10.1016/i.jsbmb.2004.03.002 
49. Nagpal S, Na S and Rathnachalam R (2005) Noncalcemic actions of vitamin D receptor ligands Endocr Rev 26 662-87 PMID: 15798098 doi: 10.1210/er.2004-0002

50. Colston K, Colston MJ and Feldman D (1981) 1,25dihydroxyvitamin D3 and malignant melanoma: the presence of receptors and inhibition of cell growth in culture Endocrinology 108 1083-6 PMID: 6257495 doi: 10.1210/endo-108-3-1083

51. Haussler MR, Haussler CA, Jurutka PW et al (1997) The vitamin $D$ hormone and its nuclear receptor:molecular actions and disease states J Endocrinol 154 Suppl:S57S73. PMID: 9379138

52. Uitterlinden $A G$, Fang $Y$, van Meurs JB, van Leeuwen $H$ and Pols HA (2004) Vitamin D receptor gene polymorphisms in relation to Vitamin $D$ related disease states J Steroid Biochem Mol Biol 89-90 187-93 PMID: $\underline{15225770}$ doi: 10.1016/j.jsbmb.2004.03.083

53. Sillanpaa P, Hirvonen A, Kataja V et al (2004) Vitamin D receptor gene polymorphism as an important modifier of positive family history related breast cancer risk Pharmacogenetics 14 239-45 PMID: 15083068 doi: 10.1097/00008571-200404000-00003

54. Gandini S, Raimondi S, Gnagnarella P, Dore JF, Maisonneuve P and Testori A (2009) Vitamin D and skin cancer:a meta-analysis Eur J Cancer 45 634-41 PMID: $\underline{19008093}$ doi: 10.1016/j.ejca.2008.10.003

55. Newton-Bishop JA, Beswick S, Randerson-Moor J et al (2009) Serum 25-Hydroxyvitamin D3 Levels Are
Associated With Breslow Thickness at Presentation and Survival From Melanoma J Clin Oncol 27 5439-44 PMID: 19770375

56. Newton Bishop J (2006) Vitamin D and survival from melanoma Melanoma Res 16 S26-S27

57. Halsall JA, Osborne JE, Potter L, Pringle JH and Hutchinson PE (2004) A novel polymorphism in the 1A promoter region of the vitamin $D$ receptor is associated with altered susceptibilty and prognosis in malignant melanoma Br J Cancer 91 765-70 PMID: 15238985

58. Santonocito C, Capizzi R, Concolino P et al (2007) Association between cutaneous melanoma, Breslow thickness and vitamin D receptor Bsml polymorphism $\mathrm{Br} J$ Dermatol 156 277-82 PMID: 17223867 doi: 10.1111/j.1365-2133.2006.07620.x

59. IARC Working Group (2008) Vitamin D and Cancer IARC Working Group Reports (Lyon, France: International Agency for Research on Cancer)

60. Bouillon R, Verstuyf A, Verlinden L et al (1995) Nonhypercalcemic pharmacological aspects of vitamin $D$ analogs Biochem Pharmacol 50 577-83 PMID: 7669059 doi: 10.1016/0006-2952(95)00121-F

61. Adams JS, Gacad MA, Baker AJ, Gonzales B and Rude RK (2005) Serum concentrations of 1,25-dihydroxyvitamin $D_{3}$ in Platyrrhini and Catarrhini: $A$ phylogenetic appraisal $A m \quad J$ Primatology 93 219-24 doi: $\underline{\text { 10.1002/ajp.1350090307 }}$ 